\title{
Dead yellow
}

Hue and cry.

\section{Tanith Lee}

This was my wedding dress. At the time people remarked on my choice of colour, but with my hair the way I had it then, it worked. I remember there were daffodils blooming. But I won't show you the photographs. No point now, is there?

When did it start? Officially in 2036. But the papers had been reporting curious anomalies for years before that. And people spotting things. Thinking at first the fault was in them and getting frightened - so many medical case-notes.

And I? Oh, I think I first properly noticed that day when we walked in the park. We often did that, then. It was a nice park, lots of trees, wild areas. But I heard a child - it's funny, isn't it, the way children always ask the truly awful question? - this child said to some adult, "Why are all the trees going brown?" And it was late May, you understand, early summer, and the leaves flooding out and the grass high and everything lush. What did the adult reply? I can't recall. But as we walked on, the scales, as they say, dropped from my eyes. I wish they hadn't. I began to see it too.

It wasn't like it is nowadays. Then it was only just establishing itself, the - what did they call it? - The Phenomenon.

It was almost like looking through a photographic lens. Except, obviously, this lens didn't completely change everything, as normally it would.

Neither of us said anything to the other. But I realized he, my husband, had also in those moments begun to see. We kept talking and joking, we even stopped for coffee and a doughnut at the park café. But an uneasy shadow was settling on us, and a silence.

We didn't actually discuss anything for several weeks. One evening we were making dinner, and - I remember so vividly - he was suddenly staring at the counter and he said, "What colour is that pepper, would you say?"

"Sort of orange, I suppose," I said, "an orange pepper."
"No," he said, "it's a brown pepper. And the lettuce, that's a pale brown lettuce, only its edges are ... pale blue."

And we had become two statues, while the cooker bubbled carelessly, and then he said, "Someone at work went for his eye-test today. He'd told me he was afraid he was going blind. But his problem isn't caused by any defect in his vision. The optician said, apparently, the problem is

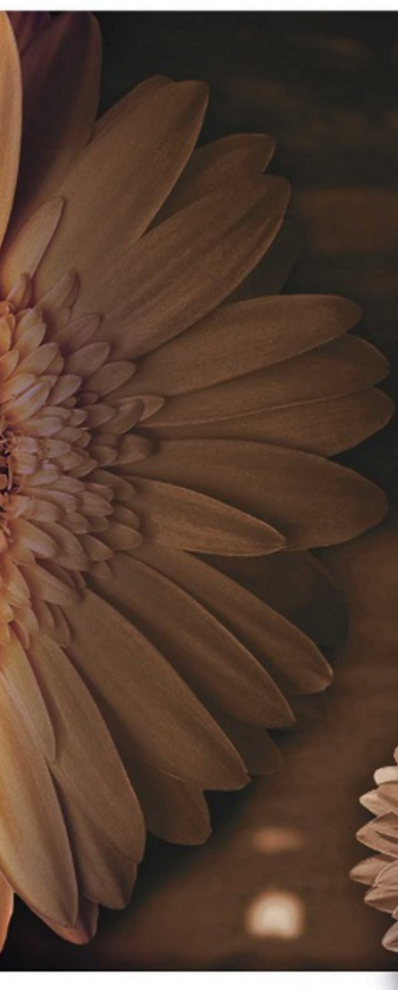

becoming universal."

And then, as if we must, we looked around us, at all and everything: the brown curtains that had been a deep green, and the green trees beyond the windows that were the colour of sludge, yes, even in the evening light - where the blue sky was somehow wrong and the west such a dark and sullen red. In the clear glass bottle the white wine gleamed colourless as water, but the mustard in the jar was mud. And on my hand my gold wedding ring had altered to the dull metal of a tarnished, ancient penny.

"What is it?" I said.

"God knows," he said. But I don't think God, if there is God, does know either, any more than the rest of us.

We all comprehend by now, or I assume most of us must do. It's worldwide after all. Hardly anyone talks about it. Aside from very young people like yourself, who never watched it happen. It's meant a lot of make-overs, home décor, clothing - good for commerce then. Even I had my corn-blonde hair bleached dead white. Better than the stagnant-pond shade it had become. (Like my wedding dress, as you see.) And if no one wants black-brownblue cabbages and lettuces, or eggs with blind-brown centres, or the quite fresh yet decayed-looking brownish peaches and apricots, there are still things to eat. Apples and tomatoes like an old wound, doughnuts like excrement. The jewel trade suffered. Who buys a topaz? A cut emerald the size of a cat's (brown/grey) eye, is worth less than nine eurodollars - less than the price of a bottle of good (stale-tea colour) Pinot Grigio. Or black Merlot.

It's worse for animals. Those white leopards that lost their camouflage, the brown canaries that stopped breeding and died out as the leopards and the tigers did. And overhead the Sun is molten white or murky crimson, and the Moon ashes, that sometimes curdle into blood.

Because yellow was a primary colour it didn't die alone. It took green and orange with it, and virtually every other shade lost some nuance or definition. How strange. Who could ever have guessed? They said that some kind of spectrum-microbe caused this. It attacked only that one element, the colour yellow. Nothing dangerous, no need for alarm, can't harm us. Just ... hurts. No, I won't show you the photos. It affects photographs too, of course. That girl in a brown dress, the brown and bone-white daffodils...

My husband? I'm afraid he died young.

Thank you for your visit. Yes, isn't it a dramatic sunset?

Apocalyptic, you could say.

Tanith Lee: written 97 books, 261 short stories, four radio plays and two episodes of science-fiction series Blake's 7. Is married. Has cats. 